\title{
4. Inequality in educational returns in Hungary
}

\section{Tamás Keller and Péter Róbert*}

\subsection{INTRODUCTION: PREVIOUS RESEARCH AND MOTIVATION}

Research on intergenerational social mobility as well as on returns to education has a long tradition in Hungary. Father-to-son/daughter-type mobility analysis by Andorka (1990) reveals that social fluidity even increased, particularly after the Second World War, during the period of the communist transformation and rapid industrialization. This tendency, however, did not continue, as subsequent research found a decrease in social openness after the fall of communism (Róbert and Bukodi 2004).

Research based on the Blau and Duncan (1967) approach has tested the 'increased merit selection' (IMS) hypothesis (Jonsson 1992), investigating the long-term trends in the effects of social origin on educational attainment, as well as in the impact of education on achieved social status. It has found a marked fall for the influence of father's occupation for men and a more moderate decrease for women. The impact of father's education on respondent's education turned out to be more persistent, while the effect of education on the respondent's International Socio-Economic Index of Occupational Status (ISEI) score increased from the decades between the two world wars and the communist period until the end of the $1960 \mathrm{~s}$, but started to decline thereafter in the 1970s and 1980s. This curvilinear trend was more marked for women than men (Luijkx et al. 2002).

Simkus (1981), in a theoretical frame based on the theory of cultural reproduction (Bourdieu and Passeron 1977), hypothesized that the role of the school system in the status attainment process was stronger in communist countries as a result of the abolition of material inheritance. Indeed, research has confirmed that education was a major transmitter of social inequalities during the decades of communism (e.g. Ganzeboom et al. 1990).

Turning to post-communist times, a paper by Bukodi and Goldthorpe (2010) investigates the social origin-education-destination (OED) triangle 
until 2005. For the post-communist period, the authors find a decreasing trend for both the origin-education (OE) and the education-destination (ED) association, and they interpret the finding as a decrease in meritocracy under market conditions in Hungary. Moreover, the intergenerational class association (OD) becomes stronger for post-communism. Other papers confirm a significant effect of social origin on occupation and earnings after controlling for education (Blaskó and Róbert 2007; Bukodi and Róbert 2011).

Post-communist transition to the market economy led to a fundamental change in the Hungarian school system, as well as in the returns to education. The school system has become more stratified; private and church-run schools have been re-established; and the costs of tertiary education have increased. Parental financial background has thus increased its importance for achievement (Bukodi 1999). A further development is the educational expansion at the tertiary level connected - as elsewhere to the democratization and liberalization of society and to the decline of state control over education and labour (Schofer and Mayer 2005). At the beginning of the post-communist transformation, privatization and the emerging market economy generated a growing need for graduate labour which stimulated young people to enter higher education despite its greater costs. Indeed, student loans and part-time work during studies to cover increased living costs have become widespread (Róbert and Saar 2012).

Returns to education have altered to a substantial extent. Under communism, the main form of educational returns related to class position or occupational status. Status returns - that is, more schooling led to higher occupational positions - were dominant because income returns to educational investments were constrained by communist egalitarianism (Kornai 1992: 316-318). The ensuing strength of the ED association was regarded as 'meritocracy under communism', although the strength of that association was partly a consequence of the regulated school-to-work transition under the command economy. Most of these regulations have disappeared, contributing to a weakening of the association.

By contrast, wage returns to education have definitely increased under market conditions (Kertesi and Köllő 2002, 2005). Becker and Hadjar (2009) point out some unexpected consequences of educational expansion, namely the possible decline in returns to human capital investments. Indeed, Róbert (2009) detects signs of a decrease in returns to schooling with respect to ISEI, while the wage premium connected to a higher level of education seems to persist. Gáti and Róbert (2012) also find a decline in class returns to education concerning both access to the salariat and avoidance of the working class. Kolosi and Keller (2012) report the direct effect of social origin on occupation to be constant, whilst the indirect effect 
of social origin on occupation through education increases. As regards returns to education, the direct effect of education on salaries turns out to be quite stable, although the wage premium of better-educated people has slightly declined since 2003 in consequence of expansion at tertiary level, with some signs of overeducation and displacement of lower-educated by higher-educated people.

The present study elaborates on these research issues by investigating four research questions: (1) Is there a direct effect of social background on labour market success over and above the effect of own education?; (2) Does the effect of social background vary depending on the level of education achieved and, more precisely, is it weaker among those with higher education?; (3) Has the direct effect of social background declined over time?; and (4) Have the labour market returns to education varied over time?

In the next sections we first describe the data, variables and the methods applied. We then present our results on the status and wage returns to education, taking social origin into account and focusing on changes over time. The chapter ends with a discussion of the findings.

\subsection{DATA, VARIABLES AND METHODS}

This chapter uses International Social Survey Programme (ISSP) data of the 'Inequality' module from four surveys conducted in the years 1987, 1992, 1999 and 2009, since this is the only data set for Hungary including information on both income and social origin. For the purpose of the study, the four data sets were matched and respondents aged 28-65 were selected. One limitation of the data was that both occupation and earnings referred to the current situation of the respondents. However, we controlled for age and age-squared in the models, and we repeated our analysis for respondents aged 28-45, without finding significant differences in the results, except for those noted in the discussion. Occupational returns to education were analysed for all respondents who had ever worked and had valid information on the current or last job, while wage returns were analysed only for those in the labour market at the time of the survey. All models controlled for gender.

The major predictor variables in the analysis were father's occupation, ${ }^{2}$ measured with the ISEI scale (Ganzeboom et al. 1992), and respondent's level of education, measured with four categories: elementary and below (the reference category), lower-secondary (vocational training or apprenticeship), upper-secondary (eligibility for tertiary education) and tertiary level (college or university degree). As regards the dependent variables 
of the analysis, respondent's current occupation was coded into the ISEI scale, while for income the logarithm of net earnings, inflated to the 2009 price level, was used.

In order to capture the changes over time, dummies of the survey years were used (1987 was the reference). Thus, our analysis was basically in contrast with the last stage of the communist period (1987). We were then able to distinguish among three phases of the post-communist era: early transformation (1992), mature transformation (1999) and consolidated transformation (2009). This means that in time we went beyond any previous analysis on Hungary.

Table A.4.1 in the online appendix provides some descriptive information. While ISEI scores display few changes over time, the growing trend due to the industrialization of the early communist period appears stronger for fathers. Structural changes in schooling are marked, in line with the global process described above. The largest modifications in the data appear for wages, where the observed means display the inflation experienced by the Hungarian currency and the corrections mentioned above. The mean values and standard deviations of the ISEI score by level of schooling (to be found in Table A.4.2 in the online appendix) show that respondents with higher levels of schooling always ended up in jobs with higher ISEI scores, but ISEI means and standard deviations reveal a moderate decline for each category of education over time.

The models present the main effects and interactions are used to answer the research questions, like the impact of social origin by levels of education or the changes over time. We report unstandardized B coefficients from ordinary least squares (OLS) regressions with robust standard errors.

\subsection{RESULTS: OCCUPATIONAL AND INCOME RETURNS TO EDUCATION}

\subsubsection{The Direct Effect of Social Background on Labour-Market Success}

The estimates displayed in Table 4.1 disclose a significant positive direct impact of father's ISEI on respondent's ISEI and earnings (models 1 and 3). These effects become smaller but persist when level of education is controlled for, while, as expected, education gives advantages in terms of both occupation and earnings (models 2 and 4).

In regard to age, its effect on occupation proves to be insignificant, while in regard to earnings the age effect is significant and displays the usual pattern reported by econometric analyses. In model 3, a reversed U-shaped pattern is found, but it becomes moderated, when education is controlled 
Table 4.1 The effect of social origin on occupation and earnings, respondents aged 28-65, unstandardized coefficients, robust standard errors in parentheses

\begin{tabular}{|c|c|c|c|c|}
\hline Variables & $\begin{array}{l}\text { (Model 1) } \\
\text { Respondent's } \\
\text { ISEI }\end{array}$ & $\begin{array}{l}\text { (Model 2) } \\
\text { Respondent's } \\
\text { ISEI }\end{array}$ & $\begin{array}{l}\text { (Model 3) } \\
\ln \text { (Inflated } \\
\text { wage) }\end{array}$ & $\begin{array}{l}\text { (Model 4) } \\
\text { ln(Inflated } \\
\text { wage) }\end{array}$ \\
\hline Father's ISEI & $\begin{array}{l}0.339^{* * *} \\
(0.021)\end{array}$ & $\begin{array}{l}0.090^{* * *} \\
(0.017)\end{array}$ & $\begin{array}{l}0.006^{* * *} \\
(0.001)\end{array}$ & $\begin{array}{l}0.002 * * \\
(0.001)\end{array}$ \\
\hline Elementary school & & $\begin{array}{c}-16.742^{* * * *} \\
(0.563)\end{array}$ & & $\begin{array}{c}-0.268 * * * \\
(0.023)\end{array}$ \\
\hline Vocational school & & $\begin{array}{c}-9.695 * * * \\
(0.544)\end{array}$ & & $\begin{array}{l}-0.156^{* * *} \\
(0.023)\end{array}$ \\
\hline High school final exam & & ref. & & ref. \\
\hline Tertiary education & & $\begin{array}{l}14.297 * * * \\
(0.776)\end{array}$ & & $\begin{array}{l}0.292 * * * \\
(0.029)\end{array}$ \\
\hline Age & $\begin{array}{c}0.168 \\
(0.209)\end{array}$ & $\begin{array}{c}0.053 \\
(0.164)\end{array}$ & $\begin{array}{l}0.042^{* * *} \\
(0.011)\end{array}$ & $\begin{array}{l}0.035^{* * *} \\
(0.010)\end{array}$ \\
\hline Age-squared & $\begin{array}{c}-0.002 \\
(0.002)\end{array}$ & $\begin{array}{c}0.000 \\
(0.002)\end{array}$ & $\begin{array}{l}-0.000^{* * *} \\
(0.000)\end{array}$ & $\begin{array}{l}-0.000^{* * *} \\
(0.000)\end{array}$ \\
\hline Male & $\begin{array}{c}-0.917^{*} \\
(0.476)\end{array}$ & $\begin{array}{l}-1.608^{* * * *} \\
(0.387)\end{array}$ & $\begin{array}{l}0.375^{* * *} \\
(0.018)\end{array}$ & $\begin{array}{l}0.378^{* * *} \\
(0.017)\end{array}$ \\
\hline Budapest & $\begin{array}{l}3.468^{* * *} \\
(0.743)\end{array}$ & $\begin{array}{r}0.944 * \\
(0.569)\end{array}$ & $\begin{array}{l}0.229^{* * *} \\
(0.026)\end{array}$ & $\begin{array}{l}0.192^{* * * *} \\
(0.024)\end{array}$ \\
\hline Town & ref. & ref. & ref. & ref. \\
\hline Village & $\begin{array}{l}-4.278^{* * *} \\
(0.519)\end{array}$ & $\begin{array}{l}-1.485^{* * *} \\
(0.418)\end{array}$ & $\begin{array}{l}-0.093^{* * *} \\
(0.020)\end{array}$ & $\begin{array}{c}-0.041^{* *} \\
(0.019)\end{array}$ \\
\hline Year 1987 & ref. & ref. & ref. & ref. \\
\hline Year 1992 & $\begin{array}{l}-1.710^{* * *} \\
(0.653)\end{array}$ & $\begin{array}{l}-2.472 * * * \\
(0.512)\end{array}$ & $\begin{array}{l}-0.333^{* * *} \\
(0.024)\end{array}$ & $\begin{array}{l}-0.352 * * * \\
(0.022)\end{array}$ \\
\hline Year 1999 & $\begin{array}{c}0.002 \\
(0.665)\end{array}$ & $\begin{array}{c}-1.272^{* *} \\
(0.533)\end{array}$ & $\begin{array}{l}-0.362^{* * *} \\
(0.030)\end{array}$ & $\begin{array}{c}-0.396^{* * * *} \\
(0.028)\end{array}$ \\
\hline Year 2009 & $\begin{array}{c}-0.868 \\
(0.652)\end{array}$ & $\begin{array}{l}-3.632 * * * \\
(0.533)\end{array}$ & $\begin{array}{l}-0.091 \text { *** } \\
(0.026)\end{array}$ & $\begin{array}{c}-0.130^{* * *} \\
(0.024)\end{array}$ \\
\hline Constant & $\begin{array}{l}27.589 * * * \\
(4.649)\end{array}$ & $\begin{array}{l}42.455^{* * * *} \\
(3.703)\end{array}$ & $\begin{array}{l}10.349 * * * \\
(0.223)\end{array}$ & $\begin{array}{l}10.680^{* * * *} \\
(0.211)\end{array}$ \\
\hline Observations & 3623 & 3621 & 2369 & 2369 \\
\hline R-squared & 0.177 & 0.494 & 0.296 & 0.394 \\
\hline F-stat & 75.48 & 259.1 & 106.1 & 122.3 \\
\hline $\mathrm{p}$ & 0 & 0 & 0 & 0 \\
\hline
\end{tabular}

Note: $* * * \mathrm{p}<0.01, * * \mathrm{p}<0.05, * \mathrm{p}<0.1$

Source: ISSP Hungarian data files, own calculation. 
for in model 4: younger respondents are better educated, and this runs counter to the growing age effect on earnings.

The gender effect is different for occupation and earnings. Women work in jobs with higher ISEI (chiefly non-manual jobs), but males have higher wages, as typically found by research on earnings. The model also displays a clear pattern of regional inequalities: in contrast to towns, the reference category, respondents in Budapest had significantly higher job status and earnings, whereas respondents in villages, on the contrary, worked in occupations with lower ISEI scores and earned less.

There seems to be a declining trend in both occupational status and earnings over time. For ISEI, the trend is probably related to education, since it is apparent only in model 2. In regard to earnings, inflation is controlled for and wages are calculated on the basis of the 2009 data. It should also be noted that earnings are somewhat lower in the ISSP data compared with either other survey data (for example, the TARKI Household Monitor Survey) or macro data sources from the Hungarian Central Statistical Office. This may hold more strongly for the more recent ISSP surveys. Subsequent models will tell more about changes over time when we analyse the third and fourth research questions.

\subsubsection{Variation in the Effect of Social Background by Level of Education}

Table 4.2 displays the influence of social origin (father's occupation) on occupation (model 5) and earnings (model 6) by level of schooling. By including interaction terms between social origin and schooling, the model looks for answers to the questions of whether better social background can compensate for lower educational credentials; or whether social background matters less if the respondent has a higher - for example, tertiary level of schooling. In other words, the question is whether education matters more for individuals with poor social backgrounds than for those with better social origins (Breen and Luijkx 2004; Hout 2012).

The main effect of father's occupation proves to be insignificant in both models 5 and 6 . The main effect of education remains significant, with the same pattern as shown in models 2 and 4 . The interaction terms between social background and education take a positive and significant value for respondents with primary or tertiary levels of schooling as compared to upper-secondary education (model 5). On the one hand, this means that better social origin compensates for low education: social background has a positive impact on a respondent's occupation if they have had a short educational career and, therefore, cannot expect status returns to education. On the other hand, social background also increases status returns for the tertiary-educated, thus showing a curvilinear pattern. The same 
Table 4.2 Variation in the effect of social background by level of education, respondents aged 28-65, unstandardized coefficients, robust standard errors in parentheses

\begin{tabular}{|c|c|c|}
\hline Variables & $\begin{array}{c}\text { (Model 5) } \\
\text { Respondent's ISEI }\end{array}$ & $\begin{array}{c}\text { (Model 6) } \\
\ln (\text { Inflated wage })\end{array}$ \\
\hline Father's ISEI & $\begin{array}{c}0.031 \\
(0.028)\end{array}$ & $\begin{array}{c}0.001 \\
(0.001)\end{array}$ \\
\hline Elementary school & $\begin{array}{c}-20.639 * * * \\
(1.471)\end{array}$ & $\begin{array}{l}-0.320 * * * \\
(0.057)\end{array}$ \\
\hline Vocational school & $\begin{array}{l}-10.121 * * * \\
(1.492)\end{array}$ & $\begin{array}{l}-0.177 * * * \\
(0.059)\end{array}$ \\
\hline High school final exam & ref. & ref. \\
\hline Tertiary education & $\begin{array}{l}10.209 * * * \\
(1.967)\end{array}$ & $\begin{array}{l}0.257 * * * \\
(0.073)\end{array}$ \\
\hline Elementary school $\times$ Father's ISEI & $\begin{array}{l}0.131^{* * *} \\
(0.047)\end{array}$ & $\begin{array}{c}0.002 \\
(0.002)\end{array}$ \\
\hline Vocational school $\times$ Father's ISEI & $\begin{array}{c}0.003 \\
(0.043)\end{array}$ & $\begin{array}{c}0.001 \\
(0.002)\end{array}$ \\
\hline High school final exam $\times$ Father's ISEI & ref. & ref. \\
\hline Tertiary education $\times$ Father's ISEI & $\begin{array}{l}0.104 * * \\
(0.043)\end{array}$ & $\begin{array}{c}0.001 \\
(0.002)\end{array}$ \\
\hline Age & $\begin{array}{c}0.048 \\
(0.163)\end{array}$ & $\begin{array}{l}0.035^{* * *} \\
(0.010)\end{array}$ \\
\hline Age-squared & $\begin{array}{c}0.000 \\
(0.002)\end{array}$ & $\begin{array}{l}-0.000^{* * *} \\
(0.000)\end{array}$ \\
\hline Male & $\begin{array}{l}-1.602 * * * \\
(0.386)\end{array}$ & $\begin{array}{l}0.378^{* * * *} \\
(0.017)\end{array}$ \\
\hline Budapest & $\begin{array}{c}0.879 \\
(0.567)\end{array}$ & $\begin{array}{l}0.192^{* * *} \\
(0.024)\end{array}$ \\
\hline Town & ref. & ref. \\
\hline Village & $\begin{array}{l}-1.500 * * * \\
(0.419)\end{array}$ & $\begin{array}{l}-0.041^{* *} \\
(0.019)\end{array}$ \\
\hline Year 1987 & ref. & ref. \\
\hline Year 1992 & $\begin{array}{l}-2.433 * * * \\
(0.514)\end{array}$ & $\begin{array}{l}-0.351 * * * \\
(0.022)\end{array}$ \\
\hline Year 1999 & $\begin{array}{l}-1.208^{* *} \\
(0.534)\end{array}$ & $\begin{array}{l}-0.395^{* * *} \\
(0.028)\end{array}$ \\
\hline Year 2009 & $\begin{array}{l}-3.631 * * * \\
(0.531)\end{array}$ & $\begin{array}{l}-0.130^{* * *} \\
(0.024)\end{array}$ \\
\hline Constant & $\begin{array}{l}44.607 * * * \\
(3.812)\end{array}$ & $\begin{array}{l}10.712 * * * \\
(0.214)\end{array}$ \\
\hline Observations & 3621 & 2369 \\
\hline R-squared & 0.496 & 0.394 \\
\hline F-stat & 209.9 & 99.50 \\
\hline $\mathrm{p}$ & 0 & 0 \\
\hline
\end{tabular}

Note: $* * * \mathrm{p}<0.01,{ }^{* *} \mathrm{p}<0.05,{ }^{*} \mathrm{p}<0.1$.

Source: ISSP Hungarian data files, own calculation. 
interactions are not significant in the case of earnings (model 6): the impact of father's occupation on wages does not change across levels of education.

The explanation that we can offer relates to the stronger networking capability associated with a higher social origin. Generally speaking, highstatus families are better able to help their low-educated offspring reach a better occupational position than their counterparts with lower social origin. Degree-holders also seem to benefit from their advantageous social background in the growing competition among graduates for better jobs.

\subsubsection{Change in the Effect of Social Background over Time}

This research question was investigated by adding to the models the interaction terms between father's occupation and the period (survey years) dummies, as displayed in Table 4.3. Starting with the main effects, father's occupation has a significant direct influence on respondent's occupation but not on their earnings. The effect of education has the same pattern as described earlier. As regards the ISEI, the interaction terms between father's occupation and the four periods reveal no significant change over time (model 7). Given that the main effect is positive, it seems that the impact of social origin on occupation persists. Compared with the last stage of communism (the end of the 1980s), there seems to be no change in the effect of social background on occupational status. By contrast, when predicting earnings (model 8), the estimates reveal significantly stronger effects of social origin for the period between 1992 and 2009 as contrasted to the communist era (1987). Indeed, social background had no significant influence on respondent's earnings in the late communist period, when wages were more compressed, but it increasingly mattered in the postcommunist years, when income inequalities began to rise with the transition to a market economy.

\subsubsection{Change in the Returns to Education in the Labour Market over Time}

Table 4.4 displays the estimates where interaction terms between level of education and the four-period dummies are added to the regressions in order to investigate change over time in the influence of education on labour-market success. Again, the direct effects of social background are significant on both respondent's occupation (model 9) and their earnings (model 10), and there are significant occupational and wage returns to education.

Turning to the interaction terms between schooling and period, most of the estimates in model 9, predicting respondent's ISEI score, are not 
Table 4.3 Change in the effect of social background over time, respondents aged 28-65, unstandardized coefficients, robust standard errors in parentheses

\begin{tabular}{|c|c|c|}
\hline Variables & $\begin{array}{c}\text { (Model 7) } \\
\text { Respondent's ISEI }\end{array}$ & $\begin{array}{c}\text { (Model } 8) \\
\ln (\text { Inflated wage })\end{array}$ \\
\hline Father's ISEI & $\begin{array}{l}0.115^{* * *} \\
(0.023)\end{array}$ & $\begin{array}{c}-0.001 \\
(0.001)\end{array}$ \\
\hline Elementary school & $\begin{array}{c}-16.763 * * * \\
(0.564)\end{array}$ & $\begin{array}{l}-0.271^{* * * *} \\
(0.023)\end{array}$ \\
\hline Vocational school & $\begin{array}{l}-9.722^{* * *} \\
(0.546)\end{array}$ & $\begin{array}{l}-0.151^{* * *} \\
(0.023)\end{array}$ \\
\hline High school final exam & ref. & ref. \\
\hline Tertiary education & $\begin{array}{l}14.279 * * * \\
(0.779)\end{array}$ & $\begin{array}{l}0.290^{* * * *} \\
(0.029)\end{array}$ \\
\hline Year 1987 × Father's ISEI & ref. & ref. \\
\hline Year $1992 \times$ Father's ISEI & $\begin{array}{c}-0.050 \\
(0.040)\end{array}$ & $\begin{array}{c}0.003^{*} \\
(0.001)\end{array}$ \\
\hline Year $1999 \times$ Father's ISEI & $\begin{array}{c}-0.062 \\
(0.039)\end{array}$ & $\begin{array}{l}0.005^{* *} \\
(0.002)\end{array}$ \\
\hline Year 2009 × Father's ISEI & $\begin{array}{c}-0.024 \\
(0.038)\end{array}$ & $\begin{array}{l}0.006^{* * *} \\
(0.002)\end{array}$ \\
\hline Age & $\begin{array}{c}0.067 \\
(0.164)\end{array}$ & $\begin{array}{l}0.036^{* * * *} \\
(0.010)\end{array}$ \\
\hline Age-squared & $\begin{array}{c}0.000 \\
(0.002)\end{array}$ & $\begin{array}{l}-0.000 * * * \\
(0.000)\end{array}$ \\
\hline Male & $\begin{array}{l}-1.600 * * * \\
(0.387)\end{array}$ & $\begin{array}{l}0.380 * * * \\
(0.017)\end{array}$ \\
\hline Budapest & $\begin{array}{c}0.919 \\
(0.568)\end{array}$ & $\begin{array}{l}0.194 * * * \\
(0.024)\end{array}$ \\
\hline Village & $\begin{array}{l}-1.459 * * * \\
(0.419)\end{array}$ & $\begin{array}{c}-0.045^{* *} \\
(0.019)\end{array}$ \\
\hline Year 1987 & ref. & ref. \\
\hline Year 1992 & $\begin{array}{c}-0.992 \\
(1.243)\end{array}$ & $\begin{array}{l}-0.434 * * * \\
(0.051)\end{array}$ \\
\hline Year 1999 & $\begin{array}{c}0.719 \\
(1.336)\end{array}$ & $\begin{array}{l}-0.566 * * * \\
(0.074)\end{array}$ \\
\hline Year 2009 & $\begin{array}{l}-2.944 * * \\
(1.310)\end{array}$ & $\begin{array}{l}-0.320^{* * *} \\
(0.062)\end{array}$ \\
\hline Constant & $\begin{array}{l}41.382 * * * \\
(3.759)\end{array}$ & $\begin{array}{l}10.734^{* * *} \\
(0.211)\end{array}$ \\
\hline Observations & 3621 & 2369 \\
\hline R-squared & 0.494 & 0.398 \\
\hline F-stat & 209.1 & 101.6 \\
\hline $\mathrm{p}$ & 0 & 0 \\
\hline
\end{tabular}

Note: $* * * \mathrm{p}<0.01,{ }^{* *} \mathrm{p}<0.05,{ }^{*} \mathrm{p}<0.1$

Source: ISSP Hungarian data files, own calculation. 
Table 4.4 Change in the returns to education at the labour market over time, respondents aged 28-65, unstandardized coefficients, robust standard errors in parentheses

\begin{tabular}{|c|c|c|}
\hline Variables & $\begin{array}{c}\text { (Model 9) } \\
\text { Respondent's ISEI }\end{array}$ & $\begin{array}{c}\text { (Model 10) } \\
\ln (\text { Inflated wage) }\end{array}$ \\
\hline Father's ISEI & $\begin{array}{l}0.090^{* * *} \\
(0.017)\end{array}$ & $\begin{array}{l}0.002^{* *} \\
(0.001)\end{array}$ \\
\hline Elementary school & $\begin{array}{l}-17.595^{* * *} \\
(0.822)\end{array}$ & $\begin{array}{l}-0.240^{* * * *} \\
(0.027)\end{array}$ \\
\hline Vocational school & $\begin{array}{l}-10.909 * * * \\
(0.904)\end{array}$ & $\begin{array}{l}-0.115^{* * *} \\
(0.032)\end{array}$ \\
\hline High school final exam & ref. & ref. \\
\hline Tertiary education & $\begin{array}{l}13.907 * * * \\
(1.251)\end{array}$ & $\begin{array}{l}0.196^{* * *} \\
(0.036)\end{array}$ \\
\hline Elementary school $\times$ Year 1987 & ref. & ref. \\
\hline Elementary school $\times$ Year 1992 & $\begin{array}{c}0.412 \\
(1.373)\end{array}$ & $\begin{array}{c}0.003 \\
(0.059)\end{array}$ \\
\hline Elementary school $\times$ Year 1999 & $\begin{array}{l}1.858 \\
(1.419)\end{array}$ & $\begin{array}{l}-0.167 * * \\
(0.075)\end{array}$ \\
\hline Elementary school $\times$ Year 2009 & $\begin{array}{c}2.446^{*} \\
(1.454)\end{array}$ & $\begin{array}{c}-0.168 * * \\
(0.077)\end{array}$ \\
\hline Vocational school $\times$ Year 1987 & ref. & ref. \\
\hline Vocational school × Year 1992 & $\begin{array}{c}0.995 \\
(1.427)\end{array}$ & $\begin{array}{c}-0.034 \\
(0.058)\end{array}$ \\
\hline Vocational school × Year 1999 & $\begin{array}{l}1.738 \\
(1.444)\end{array}$ & $\begin{array}{l}-0.110 \\
(0.070)\end{array}$ \\
\hline Vocational school $\times$ Year 2009 & $\begin{array}{l}2.756^{* *} \\
(1.324)\end{array}$ & $\begin{array}{c}-0.071 \\
(0.055)\end{array}$ \\
\hline Tertiary education $\times$ Year 1987 & ref. & ref. \\
\hline Tertiary education $\times$ Year 1992 & $\begin{array}{l}1.006 \\
(2.163)\end{array}$ & $\begin{array}{l}0.180 * * \\
(0.075)\end{array}$ \\
\hline Tertiary education $\times$ Year 1999 & $\begin{array}{l}-1.144 \\
(2.106)\end{array}$ & $\begin{array}{c}0.157 \\
(0.096)\end{array}$ \\
\hline Tertiary education $\times$ Year 2009 & $\begin{array}{c}2.114 \\
(1.917)\end{array}$ & $\begin{array}{l}0.165^{* *} \\
(0.073)\end{array}$ \\
\hline Age & $\begin{array}{c}0.048 \\
(0.164)\end{array}$ & $\begin{array}{l}0.036^{* * *} \\
(0.010)\end{array}$ \\
\hline Age-squared & $\begin{array}{c}0.000 \\
(0.002)\end{array}$ & $\begin{array}{l}-0.000 * * * \\
(0.000)\end{array}$ \\
\hline Male & $\begin{array}{l}-1.597 * * * \\
(0.387)\end{array}$ & $\begin{array}{l}0.380^{* * *} \\
(0.017)\end{array}$ \\
\hline Budapest & $\begin{array}{c}0.915 \\
(0.570)\end{array}$ & $\begin{array}{l}0.196^{* * *} \\
(0.024)\end{array}$ \\
\hline
\end{tabular}


Table 4.4 (continued)

\begin{tabular}{|c|c|c|}
\hline Variables & $\begin{array}{c}\text { (Model 9) } \\
\text { Respondent's ISEI }\end{array}$ & $\begin{array}{c}\text { (Model 10) } \\
\ln (\text { Inflated wage) }\end{array}$ \\
\hline Town & ref. & ref. \\
\hline Village & $\begin{array}{l}-1.492^{* * *} \\
(0.419)\end{array}$ & $\begin{array}{l}-0.043^{* *} \\
(0.019)\end{array}$ \\
\hline Year 1987 & ref. & ref. \\
\hline Year 1992 & $\begin{array}{l}-2.987 * * * \\
(1.117)\end{array}$ & $\begin{array}{l}-0.365^{* * *} \\
(0.041)\end{array}$ \\
\hline Year 1999 & $\begin{array}{c}-2.189^{*} \\
(1.151)\end{array}$ & $\begin{array}{l}-0.350^{* * * *} \\
(0.052)\end{array}$ \\
\hline Year 2009 & $\begin{array}{l}-5.384 * * * \\
(1.061)\end{array}$ & $\begin{array}{l}-0.108^{* * *} \\
(0.038)\end{array}$ \\
\hline Constant & $\begin{array}{l}43.235^{* * *} \\
(3.770)\end{array}$ & $\begin{array}{l}10.649^{* * *} \\
(0.211)\end{array}$ \\
\hline Observations & 3621 & 2369 \\
\hline R-squared & 0.495 & 0.402 \\
\hline F-stat & 150.5 & 73.00 \\
\hline $\mathrm{p}$ & 0 & 0 \\
\hline
\end{tabular}

Note: $\quad * * * \mathrm{p}<0.01,{ }^{* *} \mathrm{p}<0.05,{ }^{*} \mathrm{p}<0.1$

Source: ISSP Hungarian data files, own calculation.

significant. This means that the impact of education on occupational status changed little from the late 1980s until 2009. Two exceptions appear, as those with primary or vocational education work in significantly better jobs in 2009 than in 1987. However, this particular effect is not present when model 9 is estimated for the population aged 28-45; it is thus probably more important that the model does not reveal any change in the occupational effect of a college or university degree (a result that does not change for younger respondents).

With respect to wage returns, model 10 displays significant interaction terms between education and period. However, the signs of the estimates differ for the various levels of schooling, making the overall picture nuanced. Uneducated respondents have significantly lower wages after 2000, and the pattern is similar for those with vocational training (apprenticeship), but the latter interactions are not significant statistically. On the contrary, tertiary-educated respondents receive significantly higher wages after 1990, revealing how market transition and the emerging private sector favoured the graduate labour force after the collapse of 
communism. Apparently, inequalities in wages have tended to rise under post-communism and changes in returns to education are a part of this process. The pattern of temporal changes in the effect of education on earnings is roughly the same for respondents aged $28-45$, but the increase in the effect of tertiary education is not present for this age group. This makes it reasonable to assume that ageing contributes to the increase in wage returns for graduates.

\subsection{SUMMARY AND DISCUSSION}

We can now recap and discuss the most important findings of this chapter (see Table A.4.3 in the online appendix for a synthesis). For the first research question, on the direct effect of social origin, the Hungarian case shows an influence of social background on occupational status and on earnings (models 1 and 3). The estimates for this influence become weaker but remain significant when models controlled for respondent's education (models 2 and 4). This pattern is also stable over the various models fitted to test the other research questions.

Regarding the second research question, on the variation of the impact of social background by levels of schooling achieved, we found a stronger influence of father's ISEI on respondents' ISEI for those with primary or tertiary education. On the one hand, higher social background compensates for the missing educational returns in the case of the poorly educated, while on the other hand graduates with a tertiary level of schooling also benefit more than the secondary-educated respondents from their advantageous social background. This result may depend on a mechanism common to both cases: that is, the stronger networking capacity of families with higher social status. Most probably, respondents with a primary education face difficulties in finding a job and avoiding unemployment, and their families, when of higher status, can provide some support in overcoming this problem, as well as in finding a job with higher status. The same mechanism seems to be also at work among graduates who may find a job more rapidly and end up in a better occupation if they come from an advantageous parental family background, as compared with their counterparts with a worse social background.

There seems to be no such variation in the impact of social origin by levels of education when earnings are predicted, since interaction terms are not significant. However, it should be borne in mind that the wage models included only those respondents in the labour market. Consequently, negative selection into unemployment could not be controlled for, and this may 
explain the absence of a compensation effect of social background for the poorly educated.

The third research question referred to the variation in the effect of social background over time. In this regard, there seems to be no change in Hungary for social status, while the impact of social origin on earnings seems to increase over time after the end of communism. Previous studies on occupational mobility in Hungary have already reported a reversal in the declining trend in father's occupation on respondent's occupation (Luijx et al. 2002). Thus, stability, as shown by the interaction terms between social origin and period, for the current data is not in contradiction with earlier results. ${ }^{3}$ In regard to the influence of social background on earnings, even controlling for schooling, this effect was an important finding by Blaskó and Róbert (2007) and Bukodi and Róbert (2011). Thus the occurrence of the influence as such is fully in line with the expectations, while the new result of this analysis is the growing impact of social origin on earnings over time. An explanation for this is the rising income inequality - that is, the growing variation in wages - in the post-communist Hungarian market economy. In this context, social origin seems to play an increasing role in income attainment.

The analysis of the fourth research question reveals hardly any significant change in the effect of education on respondent's occupation over time. In particular, tertiary education does not yield any increased status returns over time during the three decades that we observe, from the late socialist years to the current period. Indeed, the present analysis was unable to find the decline in status returns over time expected as a consequence of educational expansion. Such a decline was found by Róbert (2009), as well as by analyses of the TARKI-Monitor data, ${ }^{4}$ but in both cases family background was not controlled for.

Contrary to occupation, however, there is a significant increase in the wage returns to education over time after the collapse of communism. In the current transformation period, schooling seems to discriminate for earnings more than in the socialist era. Respondents with primary or vocational educations receive lower wages, while graduates enjoy higher earnings after 2000 than in the 1990s or at the end of the 1980s. Our findings thus confirm the rising wage returns to higher education in Hungary found by Kertesi and Köllő (2002, 2005), Róbert (2009) and Kolosi and Keller (2012).

An important limitation of our analysis is that we predicted current occupation and earnings and our results might consequently be affected by the ageing effect. However, estimations in the models for the age groups of 28-65 and of 28-45 did not show much difference. We also controlled for age (linear and quadratic terms) and found deviating patterns. For occupation, no significant age effect appeared. This is an important result, 
although investigating temporal changes in the age effect on status attainment was not an aim of the study. Under socialism, occupational status used to increase with age, producing a 'seniority effect': older people moved up the career ladder and worked in better jobs, with a higher-level ISEI score. This seems no longer to be the case. The inverted U-curve pattern of age, however, is present for wage returns. The linear term of age shows that older respondents tend to have higher salaries than younger ones. However, the negative sign of the estimate for the quadratic term of age shows that the increase in earnings is not fully linear and comes to a halt at some time. In sum, we believe that we were able to control for the ageing effect in an acceptable manner.

Finally, two further demographic features are worth mentioning. There is a typical but not surprising or exceptional gender difference in Hungary, namely that women have higher job status but, nevertheless, men have higher earnings. Regional differences are another noteworthy element, because the study confirms that both occupational and wage returns to education are higher in Budapest and lower in the countryside.

In conclusion, we interpret our finding as a decline in equal opportunities in Hungary, because family background plays a marked role in occupational and income attainment. We have found that: (1) social origin is a significant predictor of individual occupational position and earnings (models 1-4); (2) social origin can eliminate the lack of individual effort, or even multiply its effect, at least in the case of job status (model 5); and (3) the impact of social origin has increased over time, at least in the case of earnings (model 8). Returns to schooling seem to matter more than in the past for the variation of wages (model 10).

One additional limitation of our analysis to be mentioned is that we were unable to control for the unobserved selection mechanism. Persons in the labour market are clearly a selected group of individuals, while we did not have wage information concerning the unemployed. This selection mechanism has presumably increased over time. However due to the restrictions in our data, we were unable to establish the bias in the estimated parameters caused by this sample selection. Further analysis will be needed to overcome this problem and add further details to the present findings.

\section{NOTES}

* An earlier version of this chapter was presented at the International Sociological Association's Research Committee 28 on Social Stratification and Mobility (ISA-RC28) spring meeting in Trento, 16-18 May 2013. We are grateful for comments from participants to the conference, in particular from Walter Müller, the discussant of the session. The editors of the volume have also provided several useful suggestions on the revision 
and finalization of the chapter. None of them has any responsibility for any remaining errors.

1. Mother's occupation was not collected in the earlier waves of the ISSP.

2. Note that both father's occupation and respondent's occupation are measured by the ISEI scale in this study. A more marked increase in the OD interaction has been found when researchers have applied the Erikson-Goldthorpe-Portocarero (EGP) class scheme for social origin and respondent's position (Róbert and Bukodi 2004; Bukodi and Goldthorpe 2010).

3. Four data sets from 1982, 1992, 2009 and 2010 are merged in the TARKI-Monitor data. The number of observations is more than 18000 , in order that the results might be more robust than those from the ISSP data.

\section{REFERENCES}

Andorka, R. (1990), 'Changes in social mobility in Hungary, 1930-1983', in M. Haller (ed.), Class Structure in Europe. New Findings from East-West Comparisons of Social Structure and Mobility, London: M.E. Sharpe, pp. 198-232.

Becker, R. and A. Hadjar (eds) (2009), Expected and Unexpected Consequences of the Educational Expansion in Europe and USA - Theoretical Approaches and Empirical Findings in Comparative Perspective, Bern: Haupt Verlag.

Blaskó, Z. and P. Róbert (2007), 'Graduates in the labour market: does socioeconomic background have an impact? The Case of Hungary', Czech Sociological Review, 43 (6), 1149-1173.

Blau, P.M. and O.D. Duncan (1967), The American Occupational Structure, New York: John Wiley \& Sons.

Bourdieu, P. and J.-C. Passeron (1977), Reproduction in Education, Society and Culture, London: Sage.

Breen, R. and R. Luijkx (2004), 'Conclusions', in R. Breen (ed.), Social Mobility in Europe, Oxford: Oxford University Press, pp. 383-410.

Bukodi, E. (1999), 'Educational choices in Hungary', Hungarian Statistical Review (English edition), 77, 71-94.

Bukodi, E. and J.H. Goldthorpe (2010), 'Market versus meritocracy: Hungary as a critical case', European Sociological Review, 26, 655-674.

Bukodi, E. and P. Róbert (2011), 'Education and labour market entry in transition: the case of Hungary', in I. Kogan, C. Nolke and M. Gebel (eds), Making The Transitions: Education and Labour Market Entry in Central and Eastern Europe, Stanford, CA: Stanford University Press, pp. 189-215.

Ganzeboom, H.B.G., P.M. de Graaf and P. Robert (1990), 'Cultural reproduction theory on socialist ground: intergenerational transmission of inequalities in Hungary', Research in Social Stratification and Mobility, 9, 79-104.

Ganzeboom, H.B.G., P.M. de Graaf and D. Treiman (1992), 'A Standardized International Socio-economic Index of Occupational Status', Social Science Research, 21, 1-56.

Gáti, A. and P. Róbert (2012), 'Inequality of educational returns in Hungary', unpublished manuscript.

Hout, M. (2012), 'Social and economic returns to college education in the United States', Annual Review of Sociology, 38, 379-400.

Jonsson, J.O. (1992), Towards the Merit-Selective Society?, Stockholm: Swedish Institute for Social Research, University of Stockholm. 
Kertesi, G. and J. Köllő (2002), 'Economic transformation and the revaluation of human capital - Hungary, 1986-1999', in A. de Grip, J. van Loo and K. Mayhew (eds), The Economics of Skills Obsolescence, Vol. 21, Oxford: Elsevier Science. pp. 235-273.

Kertesi, G. and J. Köllö (2005), 'The expansion of higher education highskilled unemployment, and the returns to college/university diploma', Budapest Working Papers on the Labour Market No. 3, Budapest: Institute of Economics, Hungarian Academy of Sciences (in Hungarian).

Kolosi, T. and T. Keller (2012), 'Megéri tanulni . . .? Származás, iskola, foglalkozás, kereset - utak és elágazások a rendszerváltást követően', in T. Kolosi and I.G. Tóth (eds), Társadalmi riport, Budapest: TÁRKI, pp.41-64.

Kornai, J. (1992), The Socialist System. The Political Economy of Communism, Oxford: Clarendon Press.

Luijkx, R., P. Róbert, P.M. de Graaf and H.B.G. Ganzeboom (2002), 'Changes in status attainment in Hungary between 1910 and 1989: trendless fluctuation or systematic change?', European Societies, 4 (1), 107-114.

Róbert, P. (2009), 'The consequences of educational expansion for the returns to education in Hungary', in R. Becker and A. Hadjar (eds), Expected and Unexpected Consequences of the Educational Expansion in Europe and USATheoretical Approaches and Empirical Findings in Comparative Perspective, Bern: Haupt Verlag, pp. 201-211.

Róbert, P. and E. Bukodi (2004), 'Changes in intergenerational class mobility in Hungary, 1973-2000', in R. Breen (ed.), Social Mobility in Europe, Oxford: Oxford University Press, pp. 287-314.

Róbert, P. and E. Saar (2012), 'Learning and working: the impact of the "double status position" on the labour market entry process of graduates in CEE countries', European Sociological Review, 28 (6), 742-754.

Schofer, E. and J.W. Meyer (2005), 'The worldwide expansion of higher education in the twentieth century', American Sociological Review, 70, 898-920.

Simkus, A. (1981), 'Comparative stratification and mobility', International Journal of Comparative Sociology, 22 (3), 213-236. 